\title{
Sustainability Considerations in Water-Energy-Food Nexus Research in Irrigated Agriculture
}

\author{
Ahmad Hamidov 1,2,*(D) and Katharina Helming 1,3 \\ 1 Leibniz Centre for Agricultural Landscape Research (ZALF), Eberswalder Straße 84, 15374 Müncheberg, \\ Germany; helming@zalf.de \\ 2 Tashkent Institute of Irrigation and Agricultural Mechanization Engineers (TIIAME), Kary-Niyaziy 39, \\ Tashkent 100000, Uzbekistan \\ 3 Faculty of Landscape Management and Nature Conservation, Eberswalde University for Sustainable \\ Development (HNEE), Schickler Straße 5, 16225 Eberswalde, Germany \\ * Correspondence: ahmad.hamidov@zalf.de; Tel.: +49-33-4328-2166
}

Received: 8 July 2020; Accepted: 31 July 2020; Published: 4 August 2020

\begin{abstract}
Irrigated agriculture is essential to satisfying the globally increasing demand for food and bio-based products. Yet, in water scarce regions, water-use for irrigation aggravates the competition for the use of water for other purposes, such as energy production, drinking water and sanitation. Solutions for sustainable food production through irrigated agriculture require a systemic approach to assess benefits and trade-offs across sectors. Here, the water-energy-food (WEF) nexus has become an important concept in natural resource management. It has been conceptualized to analyze linkages and trade-offs between the three sectors, across temporal and spatial scales. However, the concept has so far mainly been conceptual, with little empirical evidence or proof of concept in real world cases. The objective of this paper was to take stock of the rapidly advancing literature on the WEF nexus in irrigated agriculture, and to analyze how the concept was actually implemented in research studies, and how the nexus between water, food and energy was actually dealt with. The study period ranges from 2011 to 2019, and includes 194 articles. Results showed that the WEF nexus is indeed very relevant in irrigated agriculture, and the respective literature makes up one third of all WEF nexus papers. Modeling and empirical research have caught up with conceptual synthesis studies during the last four years, thereby indicating that the WEF nexus concept is indeed increasingly operationalized. However, most studies addressed the WEF nexus from a perspective of either socioeconomic, technological or environmental categories, and they place one of the dimensions of water, food or energy into the foreground. To address sustainable development, there is a need to fully integrate across research disciplines and thematic dimensions. Such studies are only starting to emerge. These findings are an important evidence-base for future WEF nexus research on irrigated agriculture, in support of sustainable solutions for water scarce regions, especially in settings undergoing transformations.
\end{abstract}

Keywords: sustainability; water resources; food security; energy production; soil services; transformation; governance; sustainable development goals

\section{Introduction}

Irrigated agriculture is a key example of the water-energy-food (WEF) nexus, due to the strong competition over water used for energy generation and water used for food production in water-scarce areas of the world [1-3]. Societies need to choose, for instance, between using land for food production or for renewable energy production, and between using freshwater for energy production or for irrigating crops. The components of the WEF nexus are intertwined in irrigated agriculture systems, 
and the sustainable development of the system requires an effective and coordinated management of the nexus [4]. Here, we understand the nexus as an approach whereby improved water, energy and food security can be achieved by integrating management and governance across WEF sectors and scale $[5,6]$.

Seeking to understand the interconnectedness of the three sectors of water, energy and food so as to improve cross-sectoral coordination in support of sustainable development, the WEF nexus has become an important concept in natural resource management. It has especially been operationalized to indicate the importance of the linkages between different sectors, as well as trade-offs across temporal and spatial scales in large river basins. The main findings of these studies indicate the need for robust governance [7], and the importance of state actors and politics at national and transboundary levels in reducing cross-sectoral tensions [8,9], as well as the effectiveness of formal institutions that manage trade-offs and interdependencies within the nexus approach [10]. Integrating different modeling tools has also been proposed to provide a sustainable WEF nexus at a transboundary watershed scale [11]. However, a critique has arisen regarding the rapidly spreading attention that WEF has been attracting, since it is not yet a clearly defined concept with an agreed-upon and tested framework [12]. Existing WEF studies have hardly addressed three key sustainability issues related to irrigated agriculture, namely soil degradation, nutrient loading and the application of pesticides and chemical fertilizers [13,14]. For instance, agricultural soil quality is the cornerstone of food and biomass production, for storing, filtering, transforming and recycling water and nutrients [15], and is the core component of the WEF nexus [16]. The maintenance of quality is particularly important in water-scarce dryland areas, because of these areas' vulnerability to soil salinization, a soil degradation process that is reinforced by improper irrigation practices. Soil scientists often recognize soil quality as a critical component of water, energy and food security; however, the translation of that awareness into action to enhance public recognition of the importance of soil resources is lacking $[17,18]$.

Since the introduction of the WEF nexus concept in 2011, several important critical review studies have been published focusing on different aspects of the nexus. For instance, taking a quantitative approach, Endo et al. [19] analyzed the current state of nexus research and the involvement of stakeholders from a hydrological perspective. Albrecht et al. [20] provided a comprehensive analysis of the methods employed for nexus assessments and the identification of key features for promising analytical tools. Zhang et al. [21] analyzed the current concepts and methods of the WEF nexus for urban sustainability. Roidt and Avellan [22] assessed the intended goals and features of different integrated management approaches. In this review study, we take a thematic approach, and focus on WEF studies addressing irrigated agriculture.

While scientific studies on the WEF nexus have increased notably in recent years, there are very few scientists who have tried to link the nexus with a number of sustainable development goals (SDGs). For instance, Boas et al. [23] critically examined the SDGs, proposing that the connections between many of the goals are weak and rarely structural, and do not recognize interconnections among different sectors. In contrast, for the case of South Asia, Rasul [24] suggests that the SDGs are critically important for enabling food, water and energy security in ways that do not undermine sustainability for future generations.

The primary objective of this paper was to analyze current international literature on the WEF nexus for irrigated agriculture, and its relevance to SDGs. The paper explores the state of knowledge with regard to the use of the WEF nexus for irrigated agriculture. Through a systematic qualitative review of the literature, the main added value of this research includes a determination of whether the studies follow an integrated approach across WEF sectors and consider sustainable development. Furthermore, the scope of this paper is to adopt a comprehensive viewpoint and integrate additional sustainability challenges related to irrigated agriculture, such as climate change (SDG 13) and terrestrial ecosystems (SDG 15). Finally, by building upon this review, we aim to synthesize existing knowledge, and identify existing knowledge gaps and the need for future research on sustainable WEF nexus for irrigated agriculture. 


\section{The Water-Energy-Food Nexus in the Context of Irrigated Agriculture and Sustainable Development}

Occupying nearly one fifth of the world's cropland, irrigated agriculture provides more than $40 \%$ of global food production, with approximately 280 million hectares of irrigated cropland [25]. The role of irrigated agriculture is increasing in response to increasing food demand, because of an increase in the world's population and a trend towards more bio-based products. It is essential to maintain agricultural production in water-scarce regions, especially in settings undergoing transformative process, since it is an important source of income in poor rural areas [26,27]. However, in drought prone regions, water-use for irrigation competes with the use of water for agriculture and energy production [28,29]. Irrigation plays an important part in the economic development of many countries. Figure 1 illustrates the conceptualization of WEF nexus relevance to irrigated agriculture. Introduced by the United Nations in 2015, SDGs are intended to be globally applicable, and will need to be implemented by all national governments by 2030. In this vein, developing and improving irrigation are major ways for ensuring food provision, providing rural people with employment, and thus ending poverty in many areas of the world.

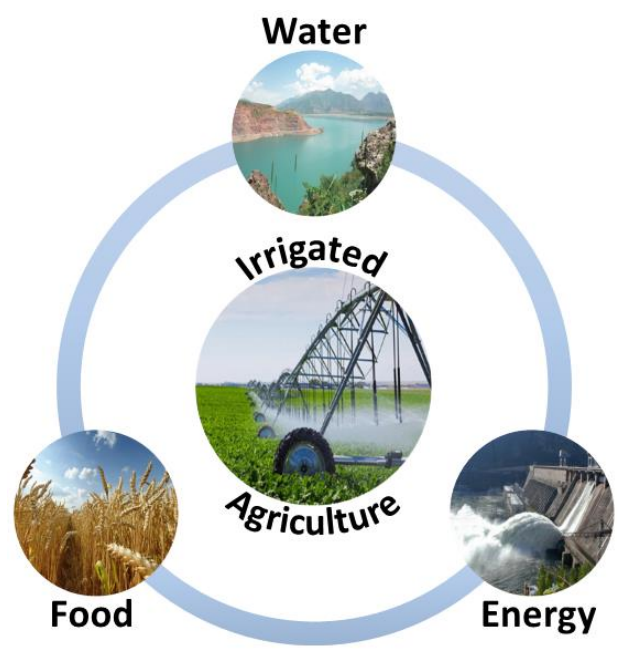

Figure 1. Relevance of water-energy-food (WEF) nexus to irrigated agriculture (own graph).

Soil salinization is one key drawback of irrigation in regions with a negative climatic water balance [30]. It can completely deteriorate the ecosystem's functions and services of the soil, and can impede the possibility of food production in the long run. Applying large amounts of water for leaching, as part of soil salinization mitigation, has been practiced on many salt-affected irrigated lands [31,32], but the amount of water required to impede soil salinization and maintain the production function of the soil is far above the water needed for crop growth. This additional water need must be considered when analyzing the WEF nexus for irrigated agriculture in the context of sustainable development. Issues related to soil degradation, including salinization, have also been raised at the forefront of United Nations SDG 15 (using terrestrial ecosystems sustainably).

WEF nexus research has emerged out of the integrated water resources management (IWRM) approach. The IWRM began attracting greater attention following the 1992 international conferences on water and environmental issues in Dublin and Rio de Janeiro [33]. The main aim of the approach was to deal with water issues in a cost-effective and sustainable way. However, the IWRM remained solely water-focused, and failed to gain the necessary cross-sectoral support to move as an integrated management concept beyond water [34]. Thus, the nexus concept has been developed by drawing on various aspects of the IWRM, sustainable agriculture, a green economy and sustainable development. The concept received much attention during the 2011 Bonn Conference titled "The water, energy and food security nexus solutions for the green economy," at which distinguished speakers presented evidence for how a nexus approach can enhance water, energy and food security by increasing 
resource-use efficiency, building synergies (mutually beneficial outcomes), minimizing trade-offs (which may potentially include non-optimal outcomes) and improving governance across sectors [5]. As a result of this conference, energy was introduced as a key aspect of the nexus. There are well-known cases where reservoir operations for hydroelectricity production might support irrigation, but hydroelectricity production may also reduce water availability for irrigated food production. This may lead to increased trade-offs between irrigation and hydropower due to reduced water availability in regions with arid and semiarid climates [35].

In terms of sustainable development, the implementation of SDGs has the potential to be a coproduct of science and policy [36,37]. The WEF nexus approach is acknowledged in three specific SDGs-SDG 2 (food security), SDG 6 (clean water) and SDG 7 (modern energy)—thus promoting the consistent integration of the nexus approach in the analysis of sustainable development [38]. In addition, SDG 13 (climate change) and SDG 15 (terrestrial ecosystems) are closely interconnected, and pertain to the use of natural resources.

\section{Methods}

We analyzed scientific publications dealing with the water-energy-food nexus and related to irrigated agriculture around the world. A systematic database search of peer-reviewed articles was conducted using the Science Citation Index Expanded (SCI-Expanded) and Social Sciences Citation Index (SSCI) database of the Web of Science (WoS) from Thomson Reuters. This database was chosen because of its comprehensiveness and high-quality records [39]. The search was conducted in January 2020, and only peer-reviewed journal articles in the English language were considered. We only selected international journal articles, to stay within the boundaries of internationally accepted scientific quality management. The study period covered nine years from 2011 to 2019. The year 2011 was selected as the start year because of the introduction of the concept for the first time. We used the following search terms in the database: "water-energy-food nexus" AND agriculture, irrigation, and soil. The latter term was chosen because of the high importance soil quality has in irrigated food production in the long term. The WEF nexus terms were used in different combinations to obtain all potential nexus-related papers, i.e., "water-energy-food" OR "water, energy, food" OR "water-food-energy" OR "water, food, energy" OR "energy-water-food" OR “energy, water, food" OR "energy-food-water" OR "energy, food, water" OR "food-water-energy" OR "food, water, energy" OR "food-energy-water" OR "food, energy, water" AND "agriculture" OR "irrigation" OR "soil". Documents were considered relevant if they matched at least one of the search terms in the title, abstract or keywords. Articles were selected if they included all three resource sectors: water, energy and food. Downloaded documents were transferred to an open EndNote library, which included information about authors, titles, abstracts, keywords, publication year, journals, page numbers, contact addresses, countries/territories and institutions. After identifying the relevant papers, we further reviewed all abstracts, and those that were deemed irrelevant to the research themes were discarded from the database. Figure 2 shows the analytical approach on which this study was based.

To understand the types of scientific methods employed in the papers, we analyzed the research methods of each paper. After a detailed review of individual papers, we divided them into two categories: review analysis and original (case study) research (participatory studies, modeling, field experiments and remote sensing analysis). We further reviewed the papers and grouped them into three research perspectives: socioeconomic and institutional perspectives, technological perspectives, and environmental management perspectives. This categorization was chosen based on the suggestion by Albrecht et al. [20] that it helps one to better understand complex interactions among multiple resource systems and policy needs.

The review also included the geographic scope of the studies and SDGs being addressed by the studies. In the former case, we followed the Food and Agriculture Organization of the United Nations' (FAO) country classification by geographical group (i.e., Australia and New Zealand, central Asia, eastern Asia, Europe, northern Africa, northern America, southern America, southern Asia and 
Sub-Saharan Africa). We used the SDGs as core narratives to classify the societal perspectives that the papers take. Finally, we carried out a detailed content analysis of the papers.

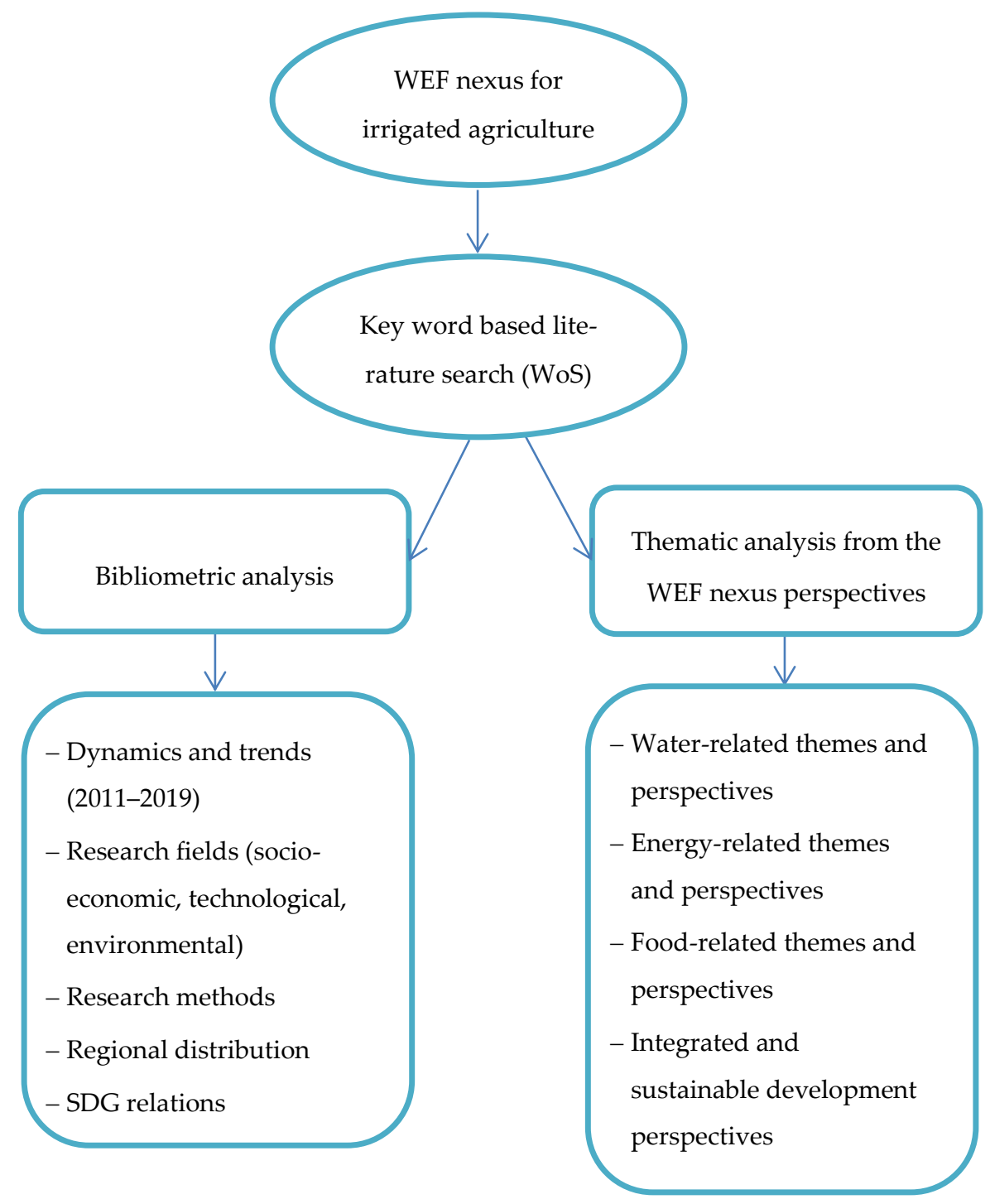

Figure 2. Analytical approach to the review of WEF nexus literature related to irrigated agriculture (own graph).

\section{Results and Discussion}

\subsection{Bibliometric Analysis of WEF Nexus Publications Related to Irrigated Agriculture}

The automated database search provided 580 WEF-related papers in total. Of these, 194 articles (approximately one third) addressed irrigated agriculture and were included in the analysis. In the remaining $66 \%$ papers, WEF nexus literature covered topics such as the following: the impacts of global climate change on the hydrological cycle, along with WEF nexus; the role of the IWRM approach at the global level and recent discourses around the WEF nexus and the green economy; the potential of hybrid floatovoltaic technology and aquaculture farming applications for improving WEF nexus sustainability; and the development of a systems framework to analyze the WEF nexus from an urban systems perspective. We noticed an annual increase in the number of selected publications during the study period, indicating that researchers were paying growing attention to the nexus approach (Figure 3). WEF-related publications dealing with irrigated agriculture peaked in 2018. In what follows, we exclusively address the WEF publications dealing with irrigated agriculture. 


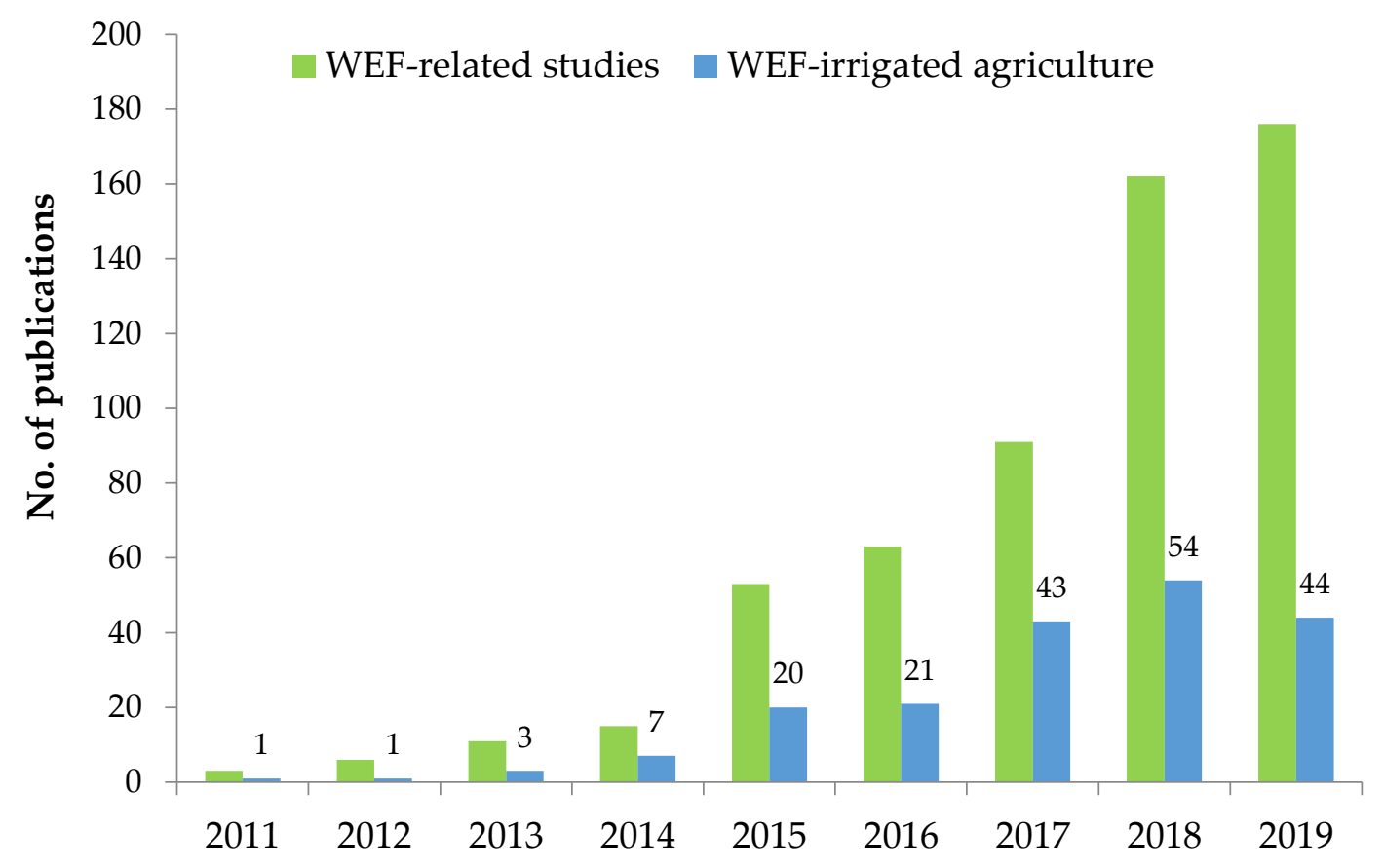

Figure 3. Number of articles on WEF-related studies and their relevance to irrigated agriculture (own graph).

In regard to research themes, about half (approximately 51\%) of the 194 papers on irrigated agriculture discuss the WEF nexus from socioeconomic and, in particular, institutional perspectives (Figure 4). Institutional innovations, governance structures, social benefits, economic return, policy design and collective action were among the themes discussed within socioeconomic and institutional perspectives. Water-use, irrigation, agricultural management and power generation were discussed as part of the technological aspects. Soil and water quality, wastewater treatment and reuse, available water quantity, vegetation, resource use efficiency as well as feedstock were discussed as part of the environmental aspects. These results contradict the findings of Albrecht et al. [20] and Keairns et al. [40], who identified the dominance of environmental themes in their reviews of WEF nexus studies. This indicates that WEF studies with a focus on irrigated agriculture are more focused on socioeconomic aspects than those on WEF nexus in general. This corroborates our earlier arguments that the WEF nexus literature addressing irrigated agriculture is less focused on environmental-related issues such as soil salinization, plant stress, nutrient loading or toxic farm chemicals. Combinations of socioeconomic and environmental perspectives were addressed in only $10 \%$ of the papers, and only two papers involved a combination of all three research themes, i.e., socioeconomic, environmental and technological. One example of an integrated analysis of the key resources, water, land and energy, is Bekchanov and Lamers [41], who presented the general framework of a system-wide economic-water-energy model that meets the requirements of an effective analytical tool dealing with water-energy-food/livelihood nexus challenges in the Aral Sea Basin in central Asia. The results highlight the essential role of an integrated analysis of WEF nexus in better-informed policy making.

The types of scientific methods used in the WEF nexus papers over time showed that review analyses were dominant in the first years, while modeling approaches emerged in constantly increasing numbers from 2013 onwards (Figure 5). This indicates that the WEF nexus was initially a conceptual approach, with little evidence about its operationalization. During the few last years, papers addressing empirical approaches, including participatory research and field experiments, have emerged in addition to modeling approaches. This follows the suggestion by Leck et al. [42], who reiterated that more sophisticated modeling systems designed to assess and quantify WEF linkage could help 
in operationalizing the nexus approach. The number of studies employing quantitative modeling approaches increased during the study period. These included a global biosphere management model [43,44], a vadose zone model [45], a hydrological model with a soil and water assessment tool [46], an agent-based model [11], a system-wide economic-water-energy model [41], a WEF Nexus Tool [47], inter alia. Only $8 \%$ of the papers employed participatory social science methods, including expert interviews [48], household surveys [49,50] and focus group discussions [51]. This is in line with Hannibal and Portney's [52] findings that the nexus research, or the connection between water, energy and food, has not been sufficiently addressed in the social sciences. Field experiments were only employed by $4 \%$ of the studies, namely, Mortensen et al. [53] on nutrient loops in arid-land rivers, Obade and Lal [54] on soil quality assessment, and Tran et al. [55] on the suitability of a sulfur-based seed solution in the development of WEF nexus technology using sulfur chemicals that contain an air pollutant. These results prove that the WEF concept is starting to be operationalized in research. However, the low number of empirical studies compared to modeling activities reveals the risk of data scarcity in the proper ground-truthing of conceptual and modeling work.

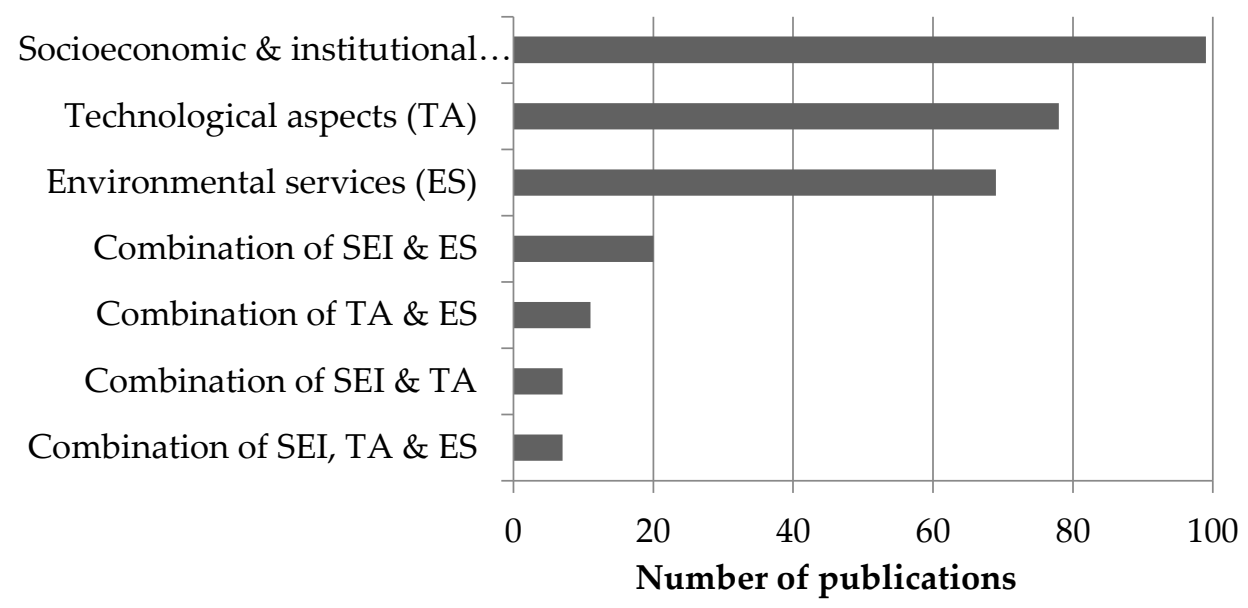

Figure 4. Research themes in the WEF nexus publications related to irrigated agriculture (own graph).

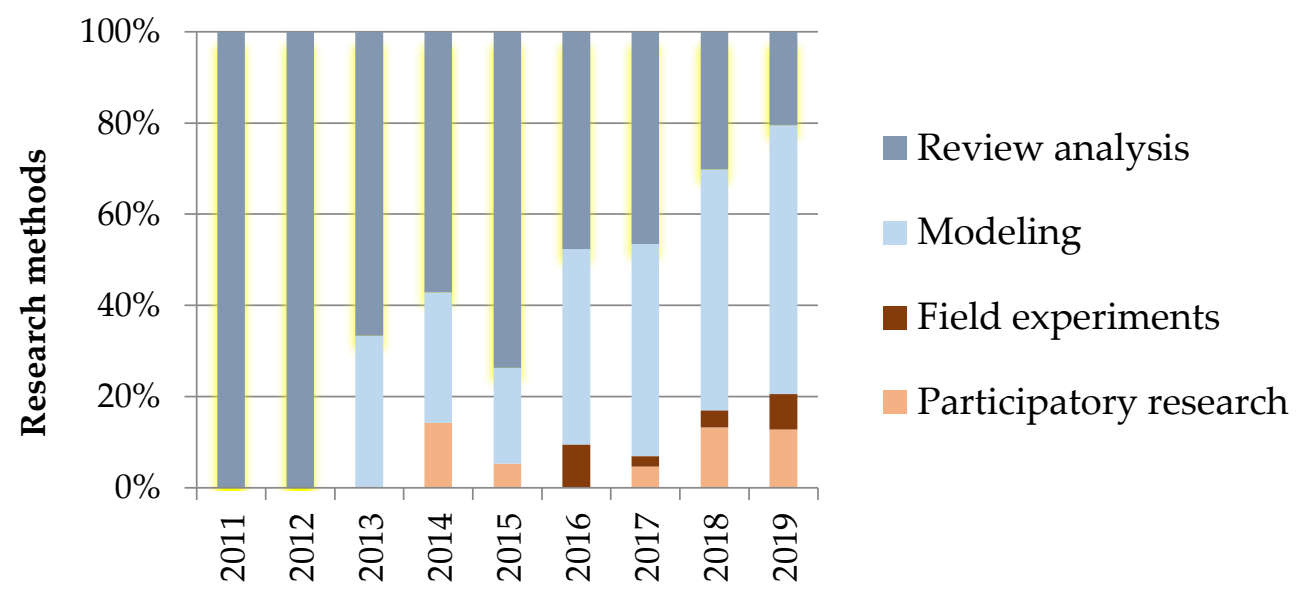

Figure 5. Share of research methods in WEF nexus publications (own graph).

Regarding the geographic scope, approximately $27 \%$ of the articles take a global perspective (Figure 6). This is because approximately $40 \%$ of the publications carried out review analysis. In terms of specific countries or regions, Europe was mostly addressed (about $15 \%$ of publications), followed by eastern Asia (13\% of publications). This is in line with the large area of irrigated agriculture in this region. Eastern Asia occupies 73.9 million ha or about 23\% of the world's total irrigated lands [56]. Two thirds of these publications are implemented in China only. North America (Canada and the 
United States) is the next region where the WEF nexus concept has been important research $(12 \%$ of publications). Despite the fact that southern Asia (e.g., Bangladesh, India, Nepal, Pakistan and Sri Lanka) has the largest irrigated land area (98 million ha), only approximately $11 \%$ (or 23 papers) apply the concept of WEF nexus to this region. In contrast, many WEF nexus-related publications exist in Sub-Saharan Africa (approximately 12\%), despite this region having a relatively small proportion of irrigated land area ( 8.2 million ha). This shows that the published WEF nexus papers relevant to irrigated agriculture are disproportionally represented with regard to total irrigated areas. Despite the fact that central Asia and southern America have relatively larger total irrigated areas, the papers on WEF nexus addressing irrigated agriculture underrepresent these geographical groups.
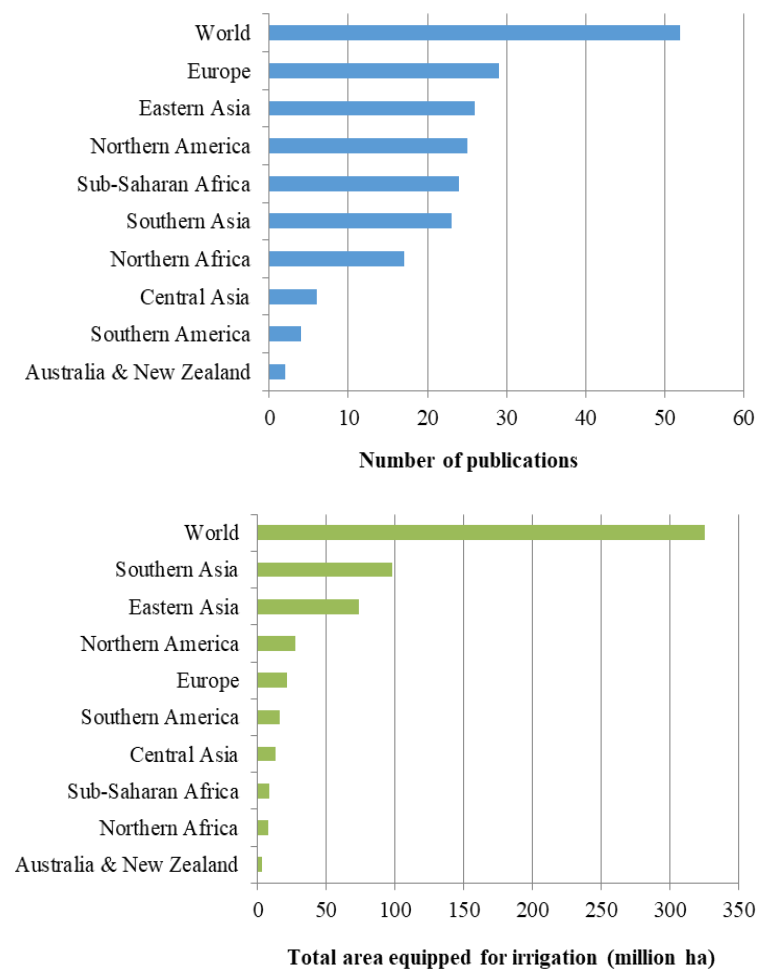

Figure 6. WEF nexus publications and potential irrigated land around the world (own graph).

We used the SDGs' classifications to analyze the thematic perspectives of the papers (Figure 7). SDGs 2, 6 and 7 provide the core narratives for the food, water and energy themes, respectively. In addition, while reviewing the papers we found that SDGs 13 and 15 were also addressed as important themes for the WEF nexus analysis related to irrigated agriculture. We looked at all combinations of different SDGs. The results indicate that even though the papers used WEF nexus terms in their titles, abstracts or keywords, the detailed review of the abstract and, in some cases, the whole paper indicated its poor linkage to all WEF sectors. The approach of WEF nexus literature to realizing a number of SDGs show that a comprehensive approach to all three sectors was implemented in only $20 \%$ of the papers. Meanwhile, $13 \%$ of papers put emphasis on covering the complex themes of sustainable water resource management (SDG 6) and access to affordable, reliable and sustainable energy (SDG 7). Approximately $6 \%$ of papers discuss food security, sustainable agriculture (SDG 2) and SDG 6 in the context of WEF nexus in irrigated agriculture. Two papers analyzed WEF nexus from an integrated management perspective, touching upon aspects of all five SDGs. For instance, the paper by Olsson et al. [57] suggested a novel model for analyzing carbon sequestration activities in dry land agriculture, considering the water-food-energy-climate nexus. Using a grasslands example in China, the authors concluded that the economic water productivity of grassland restoration was low, and that there was a need to include several of the other co-benefits to justify the use of water for 
climate change mitigation. Those co-benefits included climate change mitigation, water availability, downstream water impact, energy security, food security and moisture recycling [57].

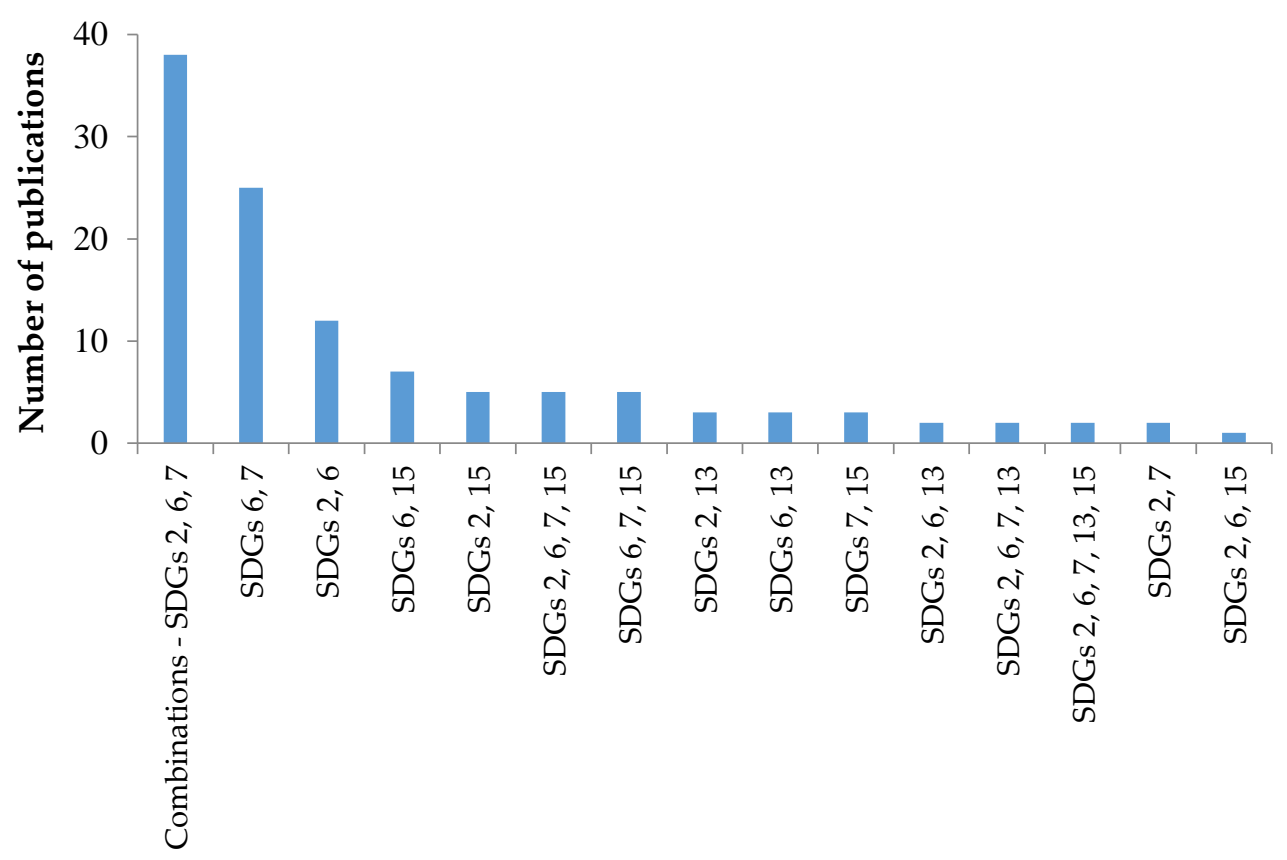

Figure 7. Thematic perspective of the WEF nexus papers with regards to sustainable development goals (own graph).

\subsection{Content Analysis of WEF Nexus Publications Related to Irrigated Agriculture from Water, Energy and Food Perspectives}

This section provides a detailed content analysis of the selected papers so as to understand the thematic focus of each paper with regards to water-related activities, energy-related activities and food-related activities, in the context of WEF nexus for irrigated agriculture. It explores the thematic activities on which the papers focused.

\subsubsection{Water-Related Activities within the WEF Nexus Related to Irrigated Agriculture}

Water is an essential resource for the human body, and plays an important role in many aspects of life. However, emerging climate change (e.g., drought, heavy rainfall), increasing water demand because of population growth, the projected shrinking of freshwater bodies available for irrigation, as well as the mismanagement of water resources (leading to soil salinization) may threaten the sustainability of the water sector. Water scarcity in agriculture may seriously limit the planet's ability to meet the growing crop demand [58]. The WEF nexus papers discuss multiple challenges related to water. These challenges include the decreasing availability of water resources, as well as the low level of water-use efficiency, water pollution, groundwater depletion, floods and droughts, outdated water infrastructure, untreated wastewater and water-related diseases (Table 1). For instance, free water and subsidized electricity in South Asia has encouraged farmers to over-exploit water resources, and has led to underinvestment in water-saving technologies [24]. North America faces challenges related to poor irrigation and wastewater quality, as well as virtual water transfer [53,59]. In the case of central Asia and Punjab, transboundary water management and dilapidated water infrastructure conditions were the main focus of the WEF nexus studies [60-62]. Jobbins et al. [63] discuss the observation that the adoption of drip irrigation by local farmers in Morocco does not necessarily reduce overall water consumption. Supporting policies for its use should be carefully addressed in order to avoid rebound effects [63]. Recent empirical evidence suggests that efficiency improvements by means of adopting water-saving irrigation technologies may, in fact, increase water consumption 
per unit area $[64,65]$. These studies highlight the proposal that the nexus approach can enhance the understanding of the interconnectedness of the sectors, and strengthen coordination among them. A bottom-up perspective, linking households, farmers and industries to WEF systems, can provide useful insights when operationalizing the WEF nexus concept [66].

Table 1. Water, energy and food themes addressed in WEF publications related to irrigated agriculture.

\begin{tabular}{|c|c|c|c|}
\hline WEF Nexus & Themes & Geographic Coverage $^{1}$ & References \\
\hline \multirow{9}{*}{ Water } & $\begin{array}{l}\text { Water availability } \\
\text { for agriculture }\end{array}$ & $\begin{array}{l}\text { Central Asia, eastern Asia, } \\
\text { Europe, southern America, } \\
\text { southern Asia, } \\
\text { Sub-Saharan Africa, World }\end{array}$ & $\begin{array}{l}\text { Closas and Rap [69], Damerau et al. [76], } \\
\text { Dhaubanjar et al. [77], Djumaboev et al. [78], } \\
\text { Guillaume et al. [79], Jalilov et al. [80], } \\
\text { Jiang [81], Karabulut et al. [46], } \\
\text { Khan et al. [11], Olsson et al. [57], } \\
\text { Paim et al. [82], Sishodia et al. [83], } \\
\text { Zamft and Conrado [84], Zeng et al. [35] }\end{array}$ \\
\hline & $\begin{array}{l}\text { Groundwater } \\
\text { management }\end{array}$ & $\begin{array}{l}\text { Central Asia, Europe, } \\
\text { northern Africa, } \\
\text { northern America, } \\
\text { southern Asia, World }\end{array}$ & $\begin{array}{l}\text { Barik et al. [85], Bekchanov and Lamers [41], } \\
\text { Closas and Rap [69], Mukherji and Das [49], } \\
\text { Pradeleix et al. [86], Sishodia et al. [83], } \\
\text { Sishodia et al. [87], Smidt et al. [88], } \\
\text { Turner et al. [89], Talozi et al. [50] }\end{array}$ \\
\hline & Floods and droughts & $\begin{array}{l}\text { Europe, northern Africa, } \\
\text { northern America, World }\end{array}$ & $\begin{array}{l}\text { Berardy and Chester [75], Daccache et al. [67], } \\
\text { DeLonge and Basche [90], Holt et al. [45], } \\
\text { Lal [91], Saladini et al. [92], } \\
\text { Van Ginkel et al. [93], Wong [94], } \\
\text { Zeng et al. [35] }\end{array}$ \\
\hline & Water-use efficiency & $\begin{array}{l}\text { Europe, northern Africa, } \\
\text { southern Asia, World }\end{array}$ & $\begin{array}{l}\text { Aguilera et al. [95], Jobbins et al. [63], } \\
\text { Rasul [96], Ravi et al. [97], Walsh et al. [72] }\end{array}$ \\
\hline & Wastewater treatment & $\begin{array}{l}\text { Northern America, } \\
\text { southern America, } \\
\text { southern Asia, World }\end{array}$ & $\begin{array}{l}\text { Holt et al. [45], Miller-Robbie et al. [70], } \\
\text { Mohareb et al. [71], Mortensen et al. [53], } \\
\text { Pan et al. [98], Rosa and D'Odorico [99], } \\
\text { Wolfe and Richard [100] }\end{array}$ \\
\hline & Water footprint & $\begin{array}{l}\text { Europe, northern Africa, } \\
\text { northern America, } \\
\text { southern Asia, } \\
\text { Sub-Saharan Africa, World }\end{array}$ & $\begin{array}{l}\text { Chini et al. [59], Daccache et al. [67], } \\
\text { de Vito et al. [101], Gusha et al. [102], } \\
\text { Ramaswami et al. [103], Vanham [104], } \\
\text { Zhang et al. [105], Zhang et al. [106] }\end{array}$ \\
\hline & Water pollution & $\begin{array}{l}\text { Eastern Asia, } \\
\text { northern America, World }\end{array}$ & $\begin{array}{l}\text { Avellan et al. [107], Chen and Zhang [108], } \\
\text { DeLonge and Basche [90], Ghani et al. [109], } \\
\text { Jiang [81] }\end{array}$ \\
\hline & Water infrastructure & $\begin{array}{l}\text { Central Asia, } \\
\text { Sub-Saharan Africa }\end{array}$ & $\begin{array}{l}\text { Bekchanov and Lamers [41], } \\
\text { Payet-Burin et al. [110], Yapiyev et al. [61] }\end{array}$ \\
\hline & Water-related diseases & Southern Asia & Rasul [24] \\
\hline \multirow{8}{*}{ Energy } & $\begin{array}{l}\text { Renewable energy (solar } \\
\text { power) infrastructure }\end{array}$ & $\begin{array}{l}\text { Europe, northern Africa, } \\
\text { northern America, } \\
\text { southern Asia, } \\
\text { Sub-Saharan Africa, World }\end{array}$ & $\begin{array}{l}\text { Bieber et al. [111], Closas and Rap [69], } \\
\text { Kilkis and Kilkis [112], Ravi et al. [97], } \\
\text { Salah et al. [113], Schwanitz et al. [114], } \\
\text { Serrano-Tovar et al. [115], Taseli and Kilkis [116], } \\
\text { Wong and Pecora [117] }\end{array}$ \\
\hline & Energy productivity & $\begin{array}{l}\text { Europe, northern Africa, } \\
\text { southern Asia }\end{array}$ & $\begin{array}{l}\text { AbdelHady et al. [118], } \\
\text { Perrone and Hornberger [119], } \\
\text { Villamayor-Tomas et al. [120], } \\
\text { Zanon et al. [121] }\end{array}$ \\
\hline & Energy footprint & $\begin{array}{l}\text { Eastern Asia, Europe, } \\
\text { northern Africa, } \\
\text { northern America, } \\
\text { southern Asia }\end{array}$ & $\begin{array}{l}\text { Daccache et al. [67], Holt et al. [45], } \\
\text { Li et al. [122], Ramaswami et al. [103], } \\
\text { Talozi et al. [50] }\end{array}$ \\
\hline & Energy efficiency & $\begin{array}{l}\text { Eastern Asia, northern } \\
\text { Africa, northern America }\end{array}$ & $\begin{array}{l}\text { Foran [123], Intralawan et al. [124], } \\
\text { Jobbins et al. [63], Mohareb et al. [71] }\end{array}$ \\
\hline & $\begin{array}{l}\text { Energy for } \\
\text { water supplies }\end{array}$ & Central Asia, southern Asia & $\begin{array}{l}\text { Djumaboev et al. [78], } \\
\text { Siddiqi and Wescoat [60] } \\
\text { Allam and Eltahir [125], Amjath-Babu et al. [126], }\end{array}$ \\
\hline & $\begin{array}{l}\text { Hydropower } \\
\text { development }\end{array}$ & $\begin{array}{l}\text { Central Asia, eastern Asia, } \\
\text { northern Africa, } \\
\text { southern Asia, World }\end{array}$ & $\begin{array}{l}\text { Dhaubanjar et al. [77], Hatamkhani and } \\
\text { Moridi [127], Intralawan et al. [124], } \\
\text { Jalilov et al. [128], Jalilov et al. [80], } \\
\text { Rasul [96], Uen et al. [129], Zeng et al. [35] }\end{array}$ \\
\hline & Bioenergy production & Europe, World & $\begin{array}{l}\text { Franz et al. [130], Moioli et al. [131], } \\
\text { Villamayor-Tomas et al. [120] }\end{array}$ \\
\hline & Subsidized energy & $\begin{array}{l}\text { Northern Africa, } \\
\text { southern Asia }\end{array}$ & Doukkali and Lejars [68], Sishodia et al. [87] \\
\hline
\end{tabular}


Table 1. Cont.

\begin{tabular}{|c|c|c|c|}
\hline WEF Nexus & Themes & Geographic Coverage $^{1}$ & References \\
\hline \multirow{5}{*}{ Food } & $\begin{array}{l}\text { Maintenance of } \\
\text { food security }\end{array}$ & $\begin{array}{l}\text { Eastern Asia, Europe, } \\
\text { northern America, } \\
\text { southern Asia, } \\
\text { Sub-Saharan Africa, World }\end{array}$ & $\begin{array}{l}\text { Barik et al. [85], De Fraiture et al. [73], } \\
\text { De Laurentiis et al. [132], Hurford and } \\
\text { Harou [133], Kattelus et al. [134], } \\
\text { Kopittke et al. [135], Lamalice et al. [136], } \\
\text { Mirzabaev et al. [137], Olsson et al. [57], } \\
\text { Rasul and Sharma [138], Wallington and } \\
\text { Cai [139], Zhang and Vesselinov [140] }\end{array}$ \\
\hline & $\begin{array}{l}\text { Increase in } \\
\text { food production }\end{array}$ & $\begin{array}{l}\text { Eastern Asia, Europe, } \\
\text { northern Africa, } \\
\text { northern America, World }\end{array}$ & $\begin{array}{l}\text { Bremer et al. [141], King and Jaafar [142], } \\
\text { Rosa et al. [143], Sanjuan-Delmas et al. [144], } \\
\text { Wang et al. [145] }\end{array}$ \\
\hline & Food supply chains & Northern America, World & $\begin{array}{l}\text { Abumhadi et al. [146], Berardy and } \\
\text { Chester [75], Damerau et al. [76], } \\
\text { Turner et al. [89] }\end{array}$ \\
\hline & Crop patterns & $\begin{array}{l}\text { Europe, northern Africa, } \\
\text { southern Asia, World }\end{array}$ & $\begin{array}{l}\text { Amjath-Babu et al. [126], Campana et al. [147], } \\
\text { El-Gafy et al. [74], Pellegrini and } \\
\text { Fernandez [148] }\end{array}$ \\
\hline & Food trade networks & Northern America & D'Odorico et al. [149], Vora et al. [150] \\
\hline
\end{tabular}

\subsubsection{Energy-Related Activities within the WEF Nexus Related to Irrigated Agriculture}

In the energy sector we find an increasing trend in the development of bio-based or renewable energy production. Most bioenergy comes from agricultural crops, forests and waste, while non bio-based renewable sources of energy are the wind, water and sun. In the WEF literature, energy aspects were discussed in the context of the energy requirements of irrigation water supply, sustainable energy solutions for off-grid farmers, the energy footprint of irrigated production, the development of bioenergy technologies, estimation of energy $\left(\mathrm{CO}_{2} \mathrm{~kg}^{-1}\right)$ productivity, the increased use of subsidized energy, and use of energy for wastewater treatment [67-70]. For instance, Siddiqi and Wescoat [60] analyzed the evolution of on-farm energy use for agriculture in Pakistan's Indus Basin irrigation system, concluding that over the last 15 years, direct energy intensity for agriculture increased by an estimated $80 \%$. As a result, there is a need to address this issue, since the country is acutely short of energy and has competing demands from industrial and domestic sectors [60]. In another study, a literature review was undertaken to provide insights into the energy implications of scaling up urban agriculture, considering direct/indirect energy pressures and interactions with other components of the WEF nexus [71]. The authors propose that gains in energy efficiency could be realized through the colocation of urban agriculture operations with waste streams (e.g., heat, $\mathrm{CO}_{2}$, graywater, wastewater and compost), which may increase yields and offset lifecycle energy demands. In terms of bioenergy production, Walsh et al. [72] focused on the development of terrestrial bioenergy technologies using algal food production, which can promote reductions in land-use change emissions through the offset of conventional farming.

\subsubsection{Food-Related Activities within the WEF Nexus Related to Irrigated Agriculture}

The WEF nexus literature discusses a number of issues related to food, including global food supply chains, meeting the food demands of humanity, maintenance of food security, increases in food production, food trade networks, cropping patterns and sustaining livelihoods (Table 1). With a growing population, it is likely that the role of irrigated agriculture in ensuring food security will become more important. Particularly, it will be challenging to increase global food supply during the 21st century given the decreasing water resources and increasing threats from climate change. For instance, meeting growing food demands in a densely populated country such as India is a major challenge [24]. The author highlights that in the context of the WEF nexus, greater policy coherence is critical for increased food production from water and in moving to a sustainable and efficient use of water and energy resources. Integrated approaches to food production are therefore necessary 
to ensure sustainability, which will also lead to higher benefits per unit of water [73]. Moreover, El-Gafy et al. [74] compared the nexus and non-nexus approaches in order to identify an optimal cropping pattern that considers water, energy and economic parameters. The study concluded that the nexus approach was best for identifying an optimal cropping pattern, because the approach is a holistic method. In another study, using a dynamic simulation model of the WEF nexus in Arizona, Berardy and Chester [75] predict that temperature increases of $1{ }^{\circ} \mathrm{C}$, and disruptions to energy and water systems for irrigation, could decrease yields by up to $12.2 \%$ in major Arizona crops, threatening the food security of Phoenix and Tucson, as well as cities that have a significant amount of food imported from Arizona, including Los Angeles, San Diego, Las Vegas and El Paso.

\subsection{Relevance of the WEF Nexus Publications to Key Challenges of Irrigated Agriculture: Integrated and Sustainable Development Perspective}

Earlier reviews have pointed out that three key sustainability issues in the context of irrigated agriculture have rarely been considered in WEF studies: (a) soil degradation, (b) nutrient loading, and (c) the intensive application of pesticides and chemical fertilizers. Our literature revealed that soil degradation was addressed in nine papers (representing $5 \%$ of the sample). For instance, Lal [91] showed the linkage of the nexus approach to soil resources, and highlighted that soil-water-energy-food are interactively linked to peace, prosperity, and ecosystem functions and services. The paper concluded that "myths about the importance of soil must be replaced by facts through research programs which create a strong credible database." Surprisingly, although soil salinization is one of the most devastating environmental problems affecting arid and semiarid regions of the world, only two studies addressed soil salinization in reference to the WEF nexus for irrigated agriculture. Abumhadi et al. [146] recognized that the impacts of global climate change on water, energy and food production are already visible, and are advancing at a higher rate than previously anticipated. More specifically, the salinization of irrigated areas has caused significant effects on global food production [146]. In another paper, Echchelh et al. [151] acknowledged that water scarcity severely affects drylands, and explored the potential for oil- and gas-produced water to irrigate food crops. The study concluded that the inappropriate use of produced water in irrigation can lead to soil salinization [151]. The issue of nutrient loading in irrigation and/or drainage water was addressed in $6 \%$ of the papers. The topic was treated in reference to the capacity of plants to take up nutrients and to filter organic matter, closing nutrient loops in arid-land rivers, the impacts of nutrients on growing fruits and vegetables, the disruption of nutrient cycles caused by agricultural activities, and the nutrient retention potential of biochar-amended soils. Avellan et al. [107] discussed the role of constructed wetlands for biomass production and for integrated management of agricultural water, energy and nutrient cycles. Finally, large applications of fertilizer and pesticides may cause a deterioration in food quality and the accumulation of heavy metals in agricultural soils. Within the WEF nexus research for irrigated agriculture, approximately $6 \%$ of papers described a link to the intensive application of pesticides and chemical fertilizers. These papers made scientific recommendations for shifting towards reduced applications of fertilizers and other inputs. However, very few papers provided specific evidence of the achievable economic benefits of reducing pesticides and chemical fertilizers, based on numerical data. Therefore, future research should be devoted to this shortcoming.

\section{Conclusions}

Since the 2011 Bonn Conference, the notion of a nexus involving water, energy and food has steadily gained attention in the literature, as evidenced by a sharp increase in WEF-related publications during 2018. However, criticism has also risen, since the WEF nexus is not yet a clearly defined concept with a standardized and tested framework. It is still at the conceptual level, with little empirical evidence. The WEF nexus literature that has focused on irrigated agriculture revealed a recently increasing operationalization of the WEF nexus concept in empirical and modeling studies, which thereby mainly take a socioeconomic perspective. 
However, we conclude that many of the studies lacked a clear cross-sectoral perspective. Although the WEF nexus research puts emphasis on cross-sectoral integration, most papers had a single-sector-oriented approach. Even though the WEF nexus is de jure a combination of water, energy and food, a detailed review of the papers indicated that a comprehensive and integrated implementation of the WEF concept in empirical research is still rare. In irrigated agriculture, the WEF concept is particularly relevant for the identification of trade-offs between sectors, and for developing solutions at the policy and management level. Here, environmental feedbacks, in particular those related to soil salinization and soil degradation, nutrient loading in irrigation and drainage water, and the spread of pesticides and other chemicals into sensitive ecosystems, need to be better addressed. Given the fact that salt-affected soils occupy about 952.2 million ha of land, or nearly $33 \%$ of the potential agricultural land area of the world [152], and is the key sustainability challenge threatening irrigated agriculture, future research studies dealing with the WEF nexus in irrigated agriculture should focus more on this challenge.

This review revealed the underrepresentation of onsite research by means of employing quantitative and/or qualitative methods of collecting data (e.g., participatory research and field experiments). Most papers were based on review and document analysis, and more recently complemented by modeling approaches. The specific understanding of the complexity of local trade-offs and the interconnectedness of the nexus requires in-depth case study research. This direction should clearly be prioritized in future research. Moreover, the published WEF nexus papers relevant to irrigated agriculture are disproportionally representative in terms of total irrigated areas. The inclusion of central Asia and southern America in future studies could further provide a comprehensive overview of the WEF nexus as related to irrigated agriculture in different geographical zones of the world. It will also be interesting to analyze whether the regional share of irrigated land reflects the magnitude of the severity of WEF nexus problems. The inclusion of "ecosystems", "biodiversity", "climate" and other relevant terms in the database search in future studies could further provide a comprehensive overview of WEF nexus studies relevant to irrigated agriculture.

Finally, our analysis focused exclusively on peer-reviewed, internationally accepted scientific journals indexed in the Web of Science database, covering the 2011-2019 period. The inclusion of grey literature is suggested in future research, and would help to increase the validity of the study and overcome the potential problems of publication bias. In particular, the authors are aware of substantial synthesis work on the WEF nexus, also in the field of irrigated agriculture, done by international organizations like the United Nations or FAO, as well as UNU Flores.

Author Contributions: A.H.: Conceptualization, Methodology, Analysis, Result interpretation, Writing—original draft preparation. K.H.: Conceptualization, Methodology, Result interpretation, Writing-reviewing and editing. All authors have read and agreed to the published version of the manuscript.

Funding: This study was funded by the Leibniz Centre for Agricultural Landscape Research (ZALF) and German Research Foundation (DFG) within the frame of WEFUz project (Sustainability assessment of the water-energy-food nexus for irrigated agriculture: Examples from river basins in Uzbekistan [GZ: HA 8522/2-1]).

Conflicts of Interest: The authors declare no conflict of interest.

\section{References}

1. Avellan, T.; Ardakanian, R.; Perret, S.R.; Ragab, R.; Vlotman, W.; Zainal, H.; Im, S.; Gany, H.A. Considering resources beyond water: Irrigation and drainage management in the context of the water-energy-food nexus. Irrig. Drain. 2018, 67, 12-21. [CrossRef]

2. Stamou, A.-T.; Rutschmann, P. Pareto optimization of water resources using the nexus approach. Water Resour. Manag. 2018, 32, 5053-5065. [CrossRef]

3. Liu, C.; Zhang, Z.Y.; Liu, S.Y.; Liu, Q.Y.; Feng, B.P.; Tanzer, J. Evaluating agricultural sustainability based on the water-energy-food nexus in the chenmengquan irrigation district of China. Sustainability 2019, 11, 5350. [CrossRef] 
4. Murzakulova, A.; Schmidt-Vogt, D.; Balla, D.; Darr, D.; Hamidov, A.; Kasymov, U.; Mendelevitch, R.; Orazgaliyev, S. Water for agriculture and other economic sectors. In The Aral Sea Basin: Water for Sustainable Development in Central Asia; Routledge: Abingdon, UK, 2020; pp. 86-99.

5. Hoff, H. Understanding the Nexus. In Background Paper for the Bonn 2011 Conference: The Water, Energy and Food Security Nexus, Bonn, Germany, 16-18 November 2011; Stockholm Environment Institute: Stockholm, Sweden, 2011.

6. Schull, V.Z.; Daher, B.; Gitau, M.W.; Mehan, S.; Flanagan, D.C. Analyzing FEW nexus modeling tools for water resources decision-making and management applications. Food Bioprod. Process. 2020, 119, 108-124. [CrossRef]

7. Salmoral, G.; Schaap, N.C.; Walschebauer, J.; Alhajaj, A. Water diplomacy and nexus governance in a transboundary context: In the search for complementarities. Sci. Total Environ. 2019, 690, 85-96. [CrossRef]

8. De Strasser, L.; Lipponen, A.; Howells, M.; Stec, S.; Brethaut, C. A methodology to assess the water energy food ecosystems nexus in Transboundary River Basins. Water 2016, 8, 59. [CrossRef]

9. Keskinen, M.; Guillaume, J.H.A.; Kattelus, M.; Porkka, M.; Rasanen, T.A.; Varis, O. The water-energy-food nexus and the transboundary context: Insights from Large Asian Rivers. Water 2016, 8, 193. [CrossRef]

10. Dombrowsky, I.; Hensengerth, O. Governing the water-energy-food nexus related to hydropower on shared rivers-The role of regional organizations. Front. Environ. Sci. 2018, 6, 153. [CrossRef]

11. Khan, H.F.; Yang, Y.C.E.; Xie, H.; Ringler, C. A coupled modeling framework for sustainable watershed management in transboundary river basins. Hydrol. Earth Syst. Sci. 2017, 21, 6275-6288. [CrossRef]

12. Venghaus, S.; Hake, J.F. Nexus thinking in current EU policies - The interdependencies among food, energy and water resources. Environ. Sci. Policy 2018, 90, 183-192. [CrossRef]

13. Bhaduri, A.; Ringler, C.; Dombrowski, I.; Mohtar, R.; Scheumann, W. Sustainability in the water-energy-food nexus. Water Int. 2015, 40, 723-732. [CrossRef]

14. Wichelns, D. The water-energy-food nexus: Is the increasing attention warranted, from either a research or policy perspective? Environ. Sci. Policy 2017, 69, 113-123. [CrossRef]

15. Hamidov, A.; Helming, K.; Bellocchi, G.; Bojar, W.; Dalgaard, T.; Ghaley, B.B.; Hoffmann, C.; Holman, I.; Holzkämper, A.; Krzeminska, D.; et al. Impacts of climate change adaptation options on soil functions: A review of European case-studies. Land Deg. Dev. 2018, 29, 2378-2389. [CrossRef]

16. Lant, C.; Baggio, J.; Konar, M.; Mejia, A.; Ruddell, B.; Rushforth, R.; Sabo, J.L.; Troy, T.J. The US food-energy-water system: A blueprint to fill the mesoscale gap for science and decision-making. Ambio 2019, 48, 251-263. [CrossRef]

17. Hatfield, J.L.; Sauer, T.J.; Cruse, R.M. Soil: The forgotten piece of the water, food, energy nexus. Adv. Agron. 2017, 143, 1-46. [CrossRef]

18. Okpara, U.T.; Fleskens, L.; Stringer, L.C.; Hessel, R.; Bachmann, F.; Daliakopoulos, I.; Berglund, K.; Velazquez, F.J.B.; Dal Ferro, N.; Keizer, J. Helping stakeholders select and apply appraisal tools to mitigate soil threats: Researchers' experiences from across Europe. J. Environ. Manag. 2020, 257, 110005. [CrossRef] [PubMed]

19. Endo, A.; Tsurita, I.; Burnett, K.; Orencio, P.M. A review of the current state of research on the water, energy, and food nexus. J. Hydrol. Reg. Stud. 2017, 11, 20-30. [CrossRef]

20. Albrecht, T.R.; Crootof, A.; Scott, C.A. The Water-Energy-Food Nexus: A systematic review of methods for nexus assessment. Environ. Res. Lett. 2018, 13, 043002. [CrossRef]

21. Zhang, P.; Zhang, L.; Chang, Y.; Xu, M.; Hao, Y.; Liang, S.; Liu, G.; Yang, Z.; Wang, C. Food-energy-water (FEW) nexus for urban sustainability: A comprehensive review. Resour. Conserv. Recycl. 2019, 142, $215-224$. [CrossRef]

22. Roidt, M.; Avellan, T. Learning from integrated management approaches to implement the Nexus. J. Environ. Manag. 2019, 237, 609-616. [CrossRef]

23. Boas, I.; Biermann, F.; Kanie, N. Cross-sectoral strategies in global sustainability governance: Towards a nexus approach. Int. Environ. Agreem. 2016, 16, 449-464. [CrossRef]

24. Rasul, G. Managing the food, water, and energy nexus for achieving the sustainable development goals in South Asia. Environ. Dev. 2016, 18, 14-25. [CrossRef]

25. Perry, C. Efficient irrigation; Inefficient communication; flawed recommendations. Irrig. Drain. 2007, 56, 367-378. [CrossRef] 
26. Hamidov, A.; Thiel, A.; Zikos, D. Institutional design in transformation: A comparative study of local irrigation governance in Uzbekistan. Environ. Sci. Policy 2015, 53, 175-191. [CrossRef]

27. Zikos, D.; Sorman, A.H.; Lau, M. Beyond water security: Asecuritisation and identity in Cyprus. Int. Environ. Agreem. 2015, 15, 309-326. [CrossRef]

28. Brelle, F. How do irrigation and drainage interventions secure food production and livelihood for rural communities? Irrig. Drain. 2016, 65, 210-213. [CrossRef]

29. Habteyes, B.G.; Ward, F.A. Economics of irrigation water conservation: Dynamic optimization for consumption and investment. J. Environ. Manag. 2020, 258, 110040. [CrossRef]

30. Hamidov, A.; Helming, K.; Balla, D. Impact of agricultural land use in Central Asia: A review. Agron. Sustain. Dev. 2016, 36, 6. [CrossRef]

31. Hamidov, A.; Beltrao, J.; Neves, A.; Khaydarova, V.; Khamidov, M. Apocynum lancifolium and Chenopodium album-Potential species to remediate saline soils. WSEAS Trans. Environ. Dev. 2007, 3, 123-128.

32. Louati, D.; Majdoub, R.; Rigane, H.; Abida, H. Effects of irrigating with saline water on soil salinization (Eastern Tunisia). Arab J. Sci. Eng. 2018, 43, 3793-3805. [CrossRef]

33. Agarwal, A.; delos Angeles, M.S.; Bhatia, R.; Chéret, I.; Davila-Poblete, S.; Falkenmark, M.; Villarreal, F.G.; Jønch-Clausen, T.; Kadi, M.A.; Kindler, J. Integrated Water Resources Management; Global Water Partnership: Stockholm, Sweden, 2000; Volume 4, p. 71, ISBN 91-630-9229-8.

34. Cai, X.; Wallington, K.; Shafiee-Jood, M.; Marston, L. Understanding and managing the food-energy-water nexus-opportunities for water resources research. Adv. Water Resour. 2018, 111, 259-273. [CrossRef]

35. Zeng, R.J.; Cai, X.M.; Ringler, C.; Zhu, T.J. Hydropower versus irrigation-an analysis of global patterns. Environ. Res. Lett. 2017, 12. [CrossRef]

36. Leach, M.; Rockström, J.; Raskin, P.; Scoones, I.; Stirling, A.C.; Smith, A.; Thompson, J.; Millstone, E.; Ely, A.; Arond, E. Transforming innovation for sustainability. Ecol. Soc. 2012, 17. [CrossRef]

37. Olawuyi, D. Sustainable development and the water-energy-food nexus: Legal challenges and emerging solutions. Environ. Sci. Policy 2020, 103, 1-9. [CrossRef]

38. Giupponi, C.; Gain, A.K. Integrated spatial assessment of the water, energy and food dimensions of the sustainable development goals. Reg. Environ. Chang. 2017, 17, 1881-1893. [CrossRef]

39. Gao, W.; Guo, H.-C. Nitrogen research at watershed scale: A bibliometric analysis during 1959-2011. Scientometrics 2014, 99, 737-753. [CrossRef]

40. Keairns, D.L.; Darton, R.C.; Irabien, A. The energy-water-food nexus. In Annual Review of Chemical and Biomolecular Engineering; Prausnitz, J.M., Ed.; Annual Reviews: Palo Alto, CA, USA, 2016; Volume 7, pp. $239-262$.

41. Bekchanov, M.; Lamers, J.P.A. The effect of energy constraints on water allocation decisions: The elaboration and application of a system-wide economic-water-energy model (SEWEM). Water 2016, 8, 253. [CrossRef]

42. Leck, H.; Conway, D.; Bradshaw, M.; Rees, J. Tracing the water-energy-food nexus: Description, theory and practice. Geogr. Compass 2015, 9, 445-460. [CrossRef]

43. Zhang, X.X.; Ermolieva, T.; Balkovic, J.; Mosnier, A.; Kraxner, F.; Liu, J.G. Recursive cross-entropy downscaling model for spatially explicit future land uses: A case study of the Heihe River Basin. Phys. Chem. Earth 2015, 89-90, 56-64. [CrossRef]

44. Ermolieva, T.; Havlik, P.; Ermoliev, Y.; Mosnier, A.; Obersteiner, M.; Leclere, D.; Khabarov, N.; Valin, H.; Reuter, W. Integrated management of land use systems under systemic risks and security targets: A stochastic global biosphere management model. J. Agric. Econ. 2016, 67, 584-601. [CrossRef]

45. Holt, N.; Shukla, S.; Hochmuth, G.; Munoz-Carpena, R.; Ozores-Hampton, M. Transforming the food-water-energy-land-economic nexus of plasticulture production through compact bed geometries. Adv. Water Resour. 2017, 110, 515-527. [CrossRef]

46. Karabulut, A.; Egoh, B.N.; Lanzanova, D.; Grizzetti, B.; Bidoglio, G.; Pagliero, L.; Bouraoui, F.; Aloe, A.; Reynaud, A.; Maes, J.; et al. Mapping water provisioning services to support the ecosystem-water-food-energy nexus in the Danube river basin. Ecosyst. Serv. 2016, 17, 278-292. [CrossRef]

47. Daher, B.; Lee, S.H.; Kaushik, V.; Blake, J.; Askariyeh, M.H.; Shafiezadeh, H.; Zamaripa, S.; Mohtar, R.H. Towards bridging the water gap in Texas: A water-energy-food nexus approach. Sci. Total Environ. 2019, 647, 449-463. [CrossRef] [PubMed]

48. Mdee, A. Disaggregating orders of water scarcity-The politics of nexus in the Wami-Ruvu River Basin, Tanzania. Water Altern. 2017, 10, 100-115. 
49. Mukherji, A.; Das, A. The political economy of metering agricultural tube wells in West Bengal, India. Water Int. 2014, 39, 671-685. [CrossRef]

50. Talozi, S.; Al Sakaji, Y.; Altz-Stamm, A. Towards a water-energy-food nexus policy: Realizing the blue and green virtual water of agriculture in Jordan. Int. J. Water Resour. Dev. 2015, 31, 461-482. [CrossRef]

51. White, D.D.; Jones, J.L.; Maciejewski, R.; Aggarwal, R.; Mascaro, G. Stakeholder analysis for the food-energy-water Nexus in Phoenix, Arizona: Implications for nexus governance. Sustainability 2017, 9, 2204. [CrossRef]

52. Hannibal, B.; Portney, K. Correlates of food-energy-water nexus awareness among the American public. Soc. Sci. Q. 2019, 100, 762-778. [CrossRef]

53. Mortensen, J.G.; Gonzalez-Pinzon, R.; Dahm, C.N.; Wang, J.J.; Zeglin, L.H.; Van Horn, D.J. Advancing the food-energy-water nexus: Closing nutrient loops in arid river corridors. Environ. Sci. Technol. 2016, 50, 8485-8496. [CrossRef]

54. Obade, V.D.; Lal, R. Towards a standard technique for soil quality assessment. Geoderma 2016, 265, 96-102. [CrossRef]

55. Tran, V.H.; Phuntsho, S.; Park, H.; Han, D.S.; Shon, H.K. Sulfur-containing air pollutants as draw solution for fertilizer drawn forward osmosis desalination process for irrigation use. Desalination 2017, 424, 1-9. [CrossRef]

56. FAO. Area Equipped for Irrigation and Percentage of Cultivated Land; Food and Agriculture Organization of the United Nations: Rome, Italy, 2016.

57. Olsson, A.; Campana, P.E.; Lind, M.; Yan, J.Y. PV water pumping for carbon sequestration in dry land agriculture. Energy Convers. Manag. 2015, 102, 169-179. [CrossRef]

58. D’Odorico, P.; Carr, J.; Dalin, C.; Dell'Angelo, J.; Konar, M.; Laio, F.; Ridolfi, L.; Rosa, L.; Suweis, S.; Tamea, S. Global virtual water trade and the hydrological cycle: Patterns, drivers, and socio-environmental impacts. Environ. Res. Lett. 2019, 14, 053001. [CrossRef]

59. Chini, C.M.; Konar, M.; Stillwell, A.S. Direct and indirect urban water footprints of the United States. Water Resour. Res. 2017, 53, 316-327. [CrossRef]

60. Siddiqi, A.; Wescoat, J.L. Energy use in large-scale irrigated agriculture in the Punjab province of Pakistan. Water Int. 2013, 38, 571-586. [CrossRef]

61. Yapiyev, V.; Sagintayev, Z.; Inglezakis, V.J.; Samarkhanov, K.; Verhoef, A. Essentials of endorheic basins and lakes: A review in the context of current and future water resource management and mitigation activities in Central Asia. Water 2017, 9, 798. [CrossRef]

62. Jalilov, S.M.; Amer, S.A.; Ward, F.A. Managing the water-energy-food nexus: Opportunities in Central Asia. J. Hydrol. 2018, 557, 407-425. [CrossRef]

63. Jobbins, G.; Kalpakian, J.; Chriyaa, A.; Legrouri, A.; El Mzouri, E. To what end? Drip irrigation and the water-energy-food nexus in Morocco. Int. J. Water Resour. Dev. 2015, 31, 393-406. [CrossRef]

64. Grafton, R.Q.; Williams, J.; Perry, C.; Molle, F.; Ringler, C.; Steduto, P.; Udall, B.; Wheeler, S.; Wang, Y.; Garrick, D. The paradox of irrigation efficiency. Science 2018, 361, 748-750. [CrossRef]

65. Paul, C.; Techen, A.-K.; Robinson, J.S.; Helming, K. Rebound effects in agricultural land and soil management: Review and analytical framework. J. Clean. Prod. 2019, 227, 154-1067. [CrossRef]

66. Scanlon, B.R.; Ruddell, B.L.; Reed, P.M.; Hook, R.I.; Zheng, C.; Tidwell, V.C.; Siebert, S. The food-energy-water nexus: Transforming science for society. Water Resour. Res. 2017, 53, 3550-3556. [CrossRef]

67. Daccache, A.; Ciurana, J.S.; Diaz, J.A.R.; Knox, J.W. Water and energy footprint of irrigated agriculture in the Mediterranean region. Environ. Res. Lett. 2014, 9, 124014. [CrossRef]

68. Doukkali, M.R.; Lejars, C. Energy cost of irrigation policy in Morocco: A social accounting matrix assessment. Int. J. Water Resour. Dev. 2015, 31, 422-435. [CrossRef]

69. Closas, A.; Rap, E. Solar-based groundwater pumping for irrigation: Sustainability, policies, and limitations. Energy Policy 2017, 104, 33-37. [CrossRef]

70. Miller-Robbie, L.; Ramaswami, A.; Amerasinghe, P. Wastewater treatment and reuse in urban agriculture: Exploring the food, energy, water, and health nexus in Hyderabad, India. Environ. Res. Lett. 2017, 12, 075005. [CrossRef]

71. Mohareb, E.; Heller, M.; Novak, P.; Goldstein, B.; Fonoll, X.; Raskin, L. Considerations for reducing food system energy demand while scaling up urban agriculture. Environ. Res. Lett. 2017, 12, 125004. [CrossRef] 
72. Walsh, M.J.; Van Doren, L.G.; Sills, D.L.; Archibald, I.; Beal, C.M.; Lei, X.G.; Huntley, M.E.; Johnson, Z.; Greene, C.H. Algal food and fuel coproduction can mitigate greenhouse gas emissions while improving land and water-use efficiency. Environ. Res. Lett. 2016, 11, 114006. [CrossRef]

73. De Fraiture, C.; Fayrap, A.; Unver, O.; Ragab, R. Integrated water management approaches for sustainable food production. Irrig. Drain. 2014, 63, 221-231. [CrossRef]

74. El-Gafy, I.; Grigg, N.; Waskom, R. Water-food-energy: Nexus and non-nexus approaches for optimal cropping pattern. Water Resour. Manag. 2017, 31, 4971-4980. [CrossRef]

75. Berardy, A.; Chester, M.V. Climate change vulnerability in the food, energy, and water nexus: Concerns for agricultural production in Arizona and its urban export supply. Environ. Res. Lett. 2017, 12. [CrossRef]

76. Damerau, K.; Patt, A.G.; van Vliet, O.P.R. Water saving potentials and possible trade-offs for future food and energy supply. Glob. Environ. Chang. 2016, 39, 15-25. [CrossRef]

77. Dhaubanjar, S.; Davidsen, C.; Bauer-Gottwein, P. Multi-objective optimization for analysis of changing trade-offs in the nepalese water-energy-food nexus with hydropower development. Water 2017, 9, 162. [CrossRef]

78. Djumaboev, K.; Yuldashev, T.; Holmatov, B.; Gafurov, Z. Assessing water use, energy use and carbon emissions in lift-irrigated areas: A case study from Karshi steppe in Uzbekistan. Irrig. Drain. 2019, 68, 409-419. [CrossRef]

79. Guillaume, J.H.A.; Kummu, M.; Eisner, S.; Varis, O. Transferable principles for managing the nexus: Lessons from historical global water modelling of Central Asia. Water 2015, 7, 4200-4231. [CrossRef]

80. Jalilov, S.M.; Keskinen, M.; Varis, O.; Amer, S.; Ward, F.A. Managing the water-energy-food nexus: Gains and losses from new water development in Amu Darya River Basin. J. Hydrol. 2016, 539, 648-661. [CrossRef]

81. Jiang, Y. China's water security: Current status, emerging challenges and future prospects. Environ. Sci. Policy 2015, 54, 106-125. [CrossRef]

82. Paim, M.A.; Salas, P.; Lindner, S.; Pollitt, H.; Mercure, J.F.; Edwards, N.R.; Vinuales, J.E. Mainstreaming the water-energy-food nexus through nationally determined contributions (NDCs): The case of Brazil. Clim. Policy 2020, 20, 163-178. [CrossRef]

83. Sishodia, R.P.; Shukla, S.; Graham, W.D.; Wani, S.P.; Jones, J.W.; Heaney, J. Current and future groundwater withdrawals: Effects, management and energy policy options for a semi-arid Indian watershed. Adv. Water Resour. 2017, 110, 459-475. [CrossRef]

84. Zamft, B.M.; Conrado, R.J. Engineering plants to reflect light: Strategies for engineering water-efficient plants to adapt to a changing climate. Plant. Biotechnol. J. 2015, 13, 867-874. [CrossRef]

85. Barik, B.; Ghosh, S.; Sahana, A.S.; Pathak, A.; Sekhar, M. Water-food-energy nexus with changing agricultural scenarios in India during recent decades. Hydrol. Earth Syst. Sci. 2017, 21, 3041-3060. [CrossRef]

86. Pradeleix, L.; Roux, P.; Bouarfa, S.; Jaouani, B.; Lili-Chabaane, Z.; Bellon-Maurel, V. Environmental impacts of contrasted groundwater pumping systems assessed by life cycle assessment methodology: Contribution to the water-energy nexus study. Irrig. Drain. 2015, 64, 124-138. [CrossRef]

87. Sishodia, R.P.; Shukla, S.; Wani, S.P.; Graham, W.D.; Jones, J.W. Future irrigation expansion outweigh groundwater recharge gains from climate change in semi-arid India. Sci. Total Environ. 2018, 635, 725-740. [CrossRef] [PubMed]

88. Smidt, S.J.; Haacker, E.M.K.; Kendall, A.D.; Deines, J.M.; Pei, L.S.; Cotterman, K.A.; Li, H.Y.; Liu, X.; Basso, B.; Hyndman, D.W. Complex water management in modern agriculture: Trends in the water-energy-food nexus over the High Plains Aquifer. Sci. Total Environ. 2016, 566, 988-1001. [CrossRef] [PubMed]

89. Turner, S.W.D.; Hejazi, M.; Calvin, K.; Kyle, P.; Kim, S. A pathway of global food supply adaptation in a world with increasingly constrained groundwater. Sci. Total Environ. 2019, 673, 165-176. [CrossRef]

90. DeLonge, M.; Basche, A. Leveraging agroecology for solutions in food, energy, and water. Elementa-Sci. Anthrop. 2017, 5. [CrossRef]

91. Lal, R. The soil-peace nexus: Our common future. Soil Sci. Plant. Nutr. 2015, 61, 566-578. [CrossRef]

92. Saladini, F.; Betti, G.; Ferragina, E.; Bouraoui, F.; Cupertino, S.; Canitano, G.; Gigliotti, M.; Autino, A.; Pulselli, F.M.; Riccaboni, A.; et al. Linking the water-energy-food nexus and sustainable development indicators for the Mediterranean region. Ecol. Indic. 2018, 91, 689-697. [CrossRef]

93. Van Ginkel, S.W.; Igou, T.; Chen, Y.S. Energy, water and nutrient impacts of California-grown vegetables compared to controlled environmental agriculture systems in Atlanta, GA. Resour. Conserv. Recycl. 2017, 122, 319-325. [CrossRef] 
94. Wong, K.V. Energy-water-food nexus and recommendations for security. J. Energy Resour. ASME 2015, 137. [CrossRef]

95. Aguilera, E.; Vila-Traver, J.; Deemer, B.R.; Infante-Amate, J.; Guzman, G.I.; de Molina, M.G. Methane emissions from artificial waterbodies dominate the carbon footprint of irrigation: A study of transitions in the food-energy-water-climate nexus (Spain, 1900-2014). Environ. Sci. Technol. 2019, 53, 5091-5101. [CrossRef]

96. Rasul, G. Food, water, and energy security in South Asia: A nexus perspective from the Hindu Kush Himalayan region. Environ. Sci. Policy 2014, 39, 35-48. [CrossRef]

97. Ravi, S.; Macknick, J.; Lobell, D.; Field, C.; Ganesan, K.; Jain, R.; Elchinger, M.; Stoltenberg, B. Colocation opportunities for large solar infrastructures and agriculture in drylands. Appl. Energy 2016, 165, 383-392. [CrossRef]

98. Pan, G.; Lyu, T.; Mortimer, R. Comment: Closing phosphorus cycle from natural waters: Re-capturing phosphorus through an integrated water-energy-food strategy. J. Environ. Sci. 2018, 65, 375-376. [CrossRef] [PubMed]

99. Rosa, L.; D'Odorico, P. The water-energy-food nexus of unconventional oil and gas extraction in the Vaca Muerta Play, Argentina. J. Clean. Prod. 2019, 207, 743-750. [CrossRef]

100. Wolfe, M.L.; Richard, T.L. 21st century engineering for on-farm food-energy-water systems. Curr. Opin. Chem. Eng. 2017, 18, 69-76. [CrossRef]

101. De Vito, R.; Pagano, A.; Portoghese, I.; Giordano, R.; Vurro, M.; Fratino, U. Integrated Approach for supporting sustainable water resources management of irrigation based on the WEFN framework. Water Resour. Manag. 2019, 33, 1281-1295. [CrossRef]

102. Gusha, M.; Dzikiti, S.; van Der Laan, M.; Steyn, M.; Manamathela, S.; Pienaar, H. Field quantification of the water footprint of an apple orchard, and extrapolation to watershed scale within a winter rainfall Mediterranean climate zone. Agr. For. Meteorol. 2019, 271, 135-147. [CrossRef]

103. Ramaswami, A.; Boyer, D.; Nagpure, A.S.; Fang, A.; Bogra, S.; Bakshi, B.; Cohen, E.; Rao-Ghorpade, A. An urban systems framework to assess the trans-boundary food-energy-water nexus: Implementation in Delhi, India. Environ. Res. Lett. 2017, 12. [CrossRef]

104. Vanham, D. Does the water footprint concept provide relevant information to address the water-foodenergy-ecosystem nexus? Ecosyst. Serv. 2016, 17, 298-307. [CrossRef]

105. Zhang, P.; Xu, Z.H.; Fan, W.G.; Ren, J.H.; Liu, R.R.; Dong, X.B. Structure dynamics and risk assessment of water-energy-food nexus: A water footprint approach. Sustainability 2019, 11, 1187. [CrossRef]

106. Zhang, Y.; Huang, K.; Yu, Y.J.; Yang, B.B. Mapping of water footprint research: A bibliometric analysis during 20062-015. J. Clean. Prod. 2017, 149, 70-79. [CrossRef]

107. Avellan, C.T.; Ardakanian, R.; Gremillion, P. The role of constructed wetlands for biomass production within the water-soil-waste nexus. Water Sci. Technol. 2017, 75, 2237-2245. [CrossRef]

108. Chen, H.G.; Zhang, Y.H.P. New biorefineries and sustainable agriculture: Increased food, biofuels, and ecosystem security. Renew. Sustain. Energy Rev. 2015, 47, 117-132. [CrossRef]

109. Ghani, W.; Salleh, M.A.M.; Adam, S.N.; Shafri, H.Z.M.; Shaharum, S.N.; Lim, K.L.; Rubinsin, N.J.; Lam, H.L.; Hasan, A.; Samsatli, S.; et al. Sustainable bio-economy that delivers the environment-food-energy-water nexus objectives: The current status in Malaysia. Food Bioprod. Process. 2019, 118, 167-186. [CrossRef]

110. Payet-Burin, R.; Kromann, M.; Pereira-Cardenal, S.; Strzepek, K.M.; Bauer-Gottwein, P. WHAT-IF: An open-source decision support tool for water infrastructure investment planning within the water-energy-food-climate nexus. Hydrol. Earth Syst. Sci. 2019, 23, 4129-4152. [CrossRef]

111. Bieber, N.; Ker, J.H.; Wang, X.N.; Triantafyllidis, C.; van Dam, K.H.; Koppelaar, R.; Shah, N. Sustainable planning of the energy-water-food nexus using decision making tools. Energy Policy 2018, 113, 584-607. [CrossRef]

112. Kilkis, S.; Kilkis, B. Integrated circular economy and education model to address aspects of an energy-water-food nexus in a dairy facility and local contexts. J. Clean. Prod. 2017, 167, 1084-1098. [CrossRef]

113. Salah, A.H.; Hassan, G.E.; Fath, H.; Elhelw, M.; Elsherbiny, S. Analytical investigation of different operational scenarios of a novel greenhouse combined with solar stills. Appl. Therm. Eng. 2017, 122, 297-310. [CrossRef]

114. Schwanitz, V.J.; Wierling, A.; Shah, P. Assessing the impact of renewable energy on regional sustainability: A comparative study of Sogn og Fjordane (Norway) and Okinawa (Japan). Sustainability 2017, 9, 1969. [CrossRef] 
115. Serrano-Tovar, T.; Suarez, B.P.; Musicki, A.; Bencomo, J.A.D.; Cabello, V.; Giampietro, M. Structuring an integrated water-energy-food nexus assessment of a local wind energy desalination system for irrigation. Sci. Total Environ. 2019, 689, 945-957. [CrossRef]

116. Taseli, B.K.; Kilkis, B. Ecological sanitation, organic animal farm, and cogeneration: Closing the loop in achieving sustainable development-A concept study with on-site biogas fueled trigeneration retrofit in a 900-bed university hospital. Energy Build. 2016, 129, 102-119. [CrossRef]

117. Wong, K.V.; Pecora, C. Recommendations for energy-water-food nexus problems. J. Energy Resour. ASME 2015, 137. [CrossRef]

118. AbdelHady, R.S.; Fahmy, H.S.; Pacini, N. Valuing of Wadi El-Rayan ecosystem through water-food-energy nexus approach. Ecohydrol. Hydrobiol. 2017, 17, 247-253. [CrossRef]

119. Perrone, D.; Hornberger, G. Frontiers of the food-energy-water trilemma: Sri Lanka as a microcosm of tradeoffs. Environ. Res. Lett. 2016, 11. [CrossRef]

120. Villamayor-Tomas, S.; Grundmann, P.; Epstein, G.; Evans, T.; Kimmich, C. The water-energy-food security nexus through the lenses of the value chain and the institutional analysis and development frameworks. Water Altern. 2015, 8, 735-755.

121. Zanon, B.D.; Roeffen, B.; Czapiewska, K.M.; de Graaf-Van Dinther, R.E.; Mooij, P.R. Potential of floating production for delta and coastal cities. J. Clean. Prod. 2017, 151, 10-20. [CrossRef]

122. Li, M.; Fu, Q.; Singh, V.P.; Ji, Y.; Liu, D.; Zhang, C.L.; Li, T.X. An optimal modelling approach for managing agricultural water-energy-food nexus under uncertainty. Sci. Total Environ. 2019, 651, 1416-1434. [CrossRef]

123. Foran, T. Node and regime: Interdisciplinary analysis of water-energy-food nexus in the Mekong Region. Water Altern. 2015, 8, 655-674.

124. Intralawan, A.; Wood, D.; Frankel, R.; Costanza, R.; Kubiszewski, I. Tradeoff analysis between electricity generation and ecosystem services in the Lower Mekong Basin. Ecosyst. Serv. 2018, 30, 27-35. [CrossRef]

125. Allam, M.M.; Eltahir, E.A.B. Water-energy-food nexus sustainability in the Upper Blue Nile (UBN) Basin. Front. Environ. Sci. 2019, 7. [CrossRef]

126. Amjath-Babu, T.S.; Sharma, B.; Brouwer, R.; Rasul, G.; Wahid, S.M.; Neupane, N.; Bhattarai, U.; Sieber, S. Integrated modelling of the impacts of hydropower projects on the water-food-energy nexus in a transboundary Himalayan river basin. Appl. Energy 2019, 239, 494-503. [CrossRef]

127. Hatamkhani, A.; Moridi, A. Multi-objective optimization of hydropower and agricultural Development at River Basin Scale. Water Resour. Manag. 2019. [CrossRef]

128. Jalilov, S.M.; Amer, S.; Ward, F. Water, food, and energy security: An elusive search for balance in Central Asia. Water Resour. Manag. 2013, 27, 3959-3979. [CrossRef]

129. Uen, T.S.; Chang, F.J.; Zhou, Y.L.; Tsai, W.P. Exploring synergistic benefits of water-food-energy nexus through multi-objective reservoir optimization schemes. Sci. Total Environ. 2018, 633, 341-351. [CrossRef] [PubMed]

130. Franz, M.; Schlitz, N.; Schumacher, K.P. Globalization and the water-energy-food nexus-Using the global production networks approach to analyze society-environment relations. Environ. Sci. Policy 2018, 90, 201-212. [CrossRef]

131. Moioli, E.; Salvati, F.; Chiesa, M.; Siecha, R.T.; Manenti, F.; Laio, F.; Rulli, M.C. Analysis of the current world biofuel production under a water-food-energy nexus perspective. Adv. Water Resour. 2018, 121, 22-31. [CrossRef]

132. De Laurentiis, V.; Hunt, D.V.L.; Rogers, C.D.F. Overcoming food security challenges within an energy/water/food nexus (EWFN) approach. Sustainability 2016, 8, 95. [CrossRef]

133. Hurford, A.P.; Harou, J.J. Balancing ecosystem services with energy and food security-Assessing trade-offs from reservoir operation and irrigation investments in Kenya's Tana Basin. Hydrol. Earth Syst. Sci. 2014, 18, 3259-3277. [CrossRef]

134. Kattelus, M.; Rahaman, M.M.; Varis, O. Myanmar under reform: Emerging pressures on water, energy and food security. Nat. Resour. Forum 2014, 38, 85-98. [CrossRef]

135. Kopittke, P.M.; Menzies, N.W.; Wang, P.; McKenna, B.A.; Lombi, E. Soil and the intensification of agriculture for global food security. Environ. Int. 2019, 132. [CrossRef]

136. Lamalice, A.; Haillot, D.; Lamontagne, M.A.; Herrmann, T.M.; Gibout, S.; Blangy, S.; Martin, J.L.; Coxam, V.; Arsenault, J.; Munro, L.; et al. Building food security in the Canadian Arctic through the development of sustainable community greenhouses and gardening. Ecoscience 2018, 25, 325-341. [CrossRef] 
137. Mirzabaev, A.; Nkonya, E.; von Braun, J. Economics of sustainable land management. Curr. Opin. Environ. Sustain. 2015, 15, 9-19. [CrossRef]

138. Rasul, G.; Sharma, B. The nexus approach to water-energy-food security: An option for adaptation to climate change. Clim. Policy 2016, 16, 682-702. [CrossRef]

139. Wallington, K.; Cai, X.M. The food-energy-water nexus: A framework to address sustainable development in the tropics. Trop. Conserv. Sci. 2017, 10. [CrossRef]

140. Zhang, X.D.; Vesselinov, V.V. Integrated modeling approach for optimal management of water, energy and food security nexus. Adv. Water Resour. 2017, 101, 1-10. [CrossRef]

141. Bremer, L.L.; Falinski, K.; Ching, C.; Wada, C.A.; Burnett, K.M.; Kukea-Shultz, K.; Reppun, N.; Chun, G.; Oleson, K.L.L.; Ticktin, T. Biocultural restoration of traditional agriculture: Cultural, environmental, and economic outcomes of Lo"i Kalo Restoration in He"eia, O"ahu. Sustainability 2018, 10, 4502. [CrossRef]

142. King, C.; Jaafar, H. Rapid assessment of the water-energy-food-climate nexus in six selected basins of North Africa and West Asia undergoing transitions and scarcity threats. Int. J. Water Resour. Dev. 2015, 31, 343-359. [CrossRef]

143. Rosa, L.; Rulli, M.C.; Davis, K.F.; Chiarelli, D.D.; Passera, C.; D'Odorico, P. Closing the yield gap while ensuring water sustainability. Environ. Res. Lett. 2018, 13. [CrossRef]

144. Sanjuan-Delmas, D.; Llorach-Massana, P.; Nadal, A.; Ercilla-Montserrat, M.; Munoz, P.; Montero, J.I.; Josa, A.; Gabarrell, X.; Rieradevall, J. Environmental assessment of an integrated rooftop greenhouse for food production in cities. J. Clean. Prod. 2018, 177, 326-337. [CrossRef]

145. Wang, Z.M.; Nguyen, T.; Westerhoff, P. Food-energy-water analysis at spatial scales for districts in the Yangtze River Basin (China). Environ. Eng. Sci. 2019, 36, 789-797. [CrossRef]

146. Abumhadi, N.; Todorovska, E.; Assenov, B.; Tsonev, S.; Vulcheva, D.; Vulchev, D.; Atanasova, L.; Savova, S.; Atanassov, A. Agricultural research in 21st century: Challenges facing the food security under the impacts of climate change. Bulg. J. Agric. Sci. 2012, 18, 801-818.

147. Campana, P.E.; Zhang, J.; Yao, T.; Andersson, S.; Landelius, T.; Melton, F.; Yan, J. Managing agricultural drought in Sweden using a novel spatially-explicit model from the perspective of water-food-energy nexus. J. Clean. Prod. 2018, 197, 1382-1393. [CrossRef]

148. Pellegrini, P.; Fernandez, R.J. Crop intensification, land use, and on-farm energy-use efficiency during the worldwide spread of the green revolution. Proc. Natl. Acad. Sci. USA 2018, 115, 2335-2340. [CrossRef] [PubMed]

149. D'Odorico, P.; Davis, K.F.; Rosa, L.; Carr, J.A.; Chiarelli, D.; Dell'Angelo, J.; Gephart, J.; MacDonald, G.K.; Seekell, D.A.; Suweis, S.; et al. The global food-energy-water nexus. Rev. Geophys. 2018, 56, 456-531. [CrossRef]

150. Vora, N.; Shah, A.; Bilec, M.M.; Khanna, V. Food-energy-water nexus: Quantifying embodied energy and GHG emissions from irrigation through virtual water transfers in food trade. ACS Sustain. Chem. Eng. 2017, 5, 2119-2128. [CrossRef]

151. Echchelh, A.; Hess, T.; Sakrabani, R. Reusing oil and gas produced water for irrigation of food crops in drylands. Agric. Water Manag. 2018, 206, 124-134. [CrossRef]

152. Artiola, J.; Walworth, J.; Musil, S.; Crimmins, M. Soil and land pollution. In Environmental and Pollution Science; Elsevier: Amsterdam, The Netherlands, 2019; pp. 219-235. [CrossRef]

(C) 2020 by the authors. Licensee MDPI, Basel, Switzerland. This article is an open access article distributed under the terms and conditions of the Creative Commons Attribution (CC BY) license (http://creativecommons.org/licenses/by/4.0/). 